\title{
On ontological approaches to academic research in architecture
}

\author{
Yonca Hurol \\ Department of Architecture, Eastern Mediterranean University, Cyprus
}

\begin{abstract}
Purpose - This study aims to define the main characteristics and possibilities of ontological approaches to research in architecture by considering content, methodologies and subject position in this type of research and questions if there is a future for this type of research or not.

Design/methodology/approach - The primary data collection method of this research is based on the ethos of the author who has taught research courses for many years. This research has also been questioned through the discussions made within a related $\mathrm{PhD}$ course.
\end{abstract}

Findings - Results of this research reveal that the spontaneous ideology of architecture might have influenced the neglection of the ontological approaches in academic research in architecture.

Social implications - Architecture has an interesting position towards reductionism because architectural thinking has ontological characteristics. The ontological approaches to academic research seems to be more applicable to architecture. However, research in architecture does not necessarily have this ontological character.

Originality/value - The "ontological approach to academic research" covers a larger set of research than the method of ontology, which is used to discuss the categories, limitations in research. Thinking on ontological approaches to research is needed because there is a considerable increase in the use of mixed research methods, which combine qualitative and quantitative research. The second reason for this is the criticisms about the unethical reductionism directed towards contemporary science by philosophers. However, there is no sufficient literature on the ontological approaches to research. This is true also for the academic research in architecture.

Keywords Ontological approaches to academic research, Academic architectural research,

The method of ontology, Ideology in research,

Spontaneous ideology in academic architectural research,

Socially and culturally sustainable architecture and urban design

Paper type Research paper

\section{Introduction}

Ontology is known as the science of being, in which the beings are separated from other beings and the continuities between them are also considered in order not to reduce the being and the other beings around it (Peirce, 1955). The main stream research approaches highlight limitations in research (which can be achieved through separations) rather than continuities. One of the primary principles of contemporary academic research is to focus on a limited subject to be able to study it extensively and to be able to carry out proper documentary research and field studies on that subject. Understanding is based on separations. Power in research also comes from the well-known principle of divide and rule.

The author of this article would like to thank the three ARCH632 students: Mustafa Batibeniz, Fiona Kavakure and Kamiar Yazdani for all the contributions they have made for this research. 
Continuities are considered together with separations within the method of ontology and ontological approaches in general.

The method of ontology is used to question categories, separations and limitations in research to avoid the problem of reductionism (Noy and McGuinness, 2000). Categories, separations and limitations enable the in-depth study of one specific subject. Reductionism in research occurs as a result of the ignorance of a factor, which alters the results of that research. Consideration of the relationship and continuity between different types of facts as well as the separations between them, are the issues of the method of ontology in research. This method has assisted research in natural, engineering and social sciences whenever it has been found necessary.

The concept of ontological approaches to academic research exists in theory sources such as Hartoonian's (1994) book called ontology of construction and philosophy sources such as that of Slavoj Zizek and it covers a wider range of research than using the method of ontology. It is also against reductionism, but it does not only question the separations and continuities in research. It questions any research object in any ontological way, which enables the covering of all considerable aspects of it. Unlike the method of ontology, which rather belongs to the main stream research (might be called positivistic or post-positivistic), other ontological approaches to research is usually required due to ideological differences, which cannot accept ignorance of certain issues, which might be easily accepted by the main stream research ideologies. For example, ignorance of harm done to nature might be accepted by some main stream research ideologies, while it might not be accepted by any critical approach. What can or cannot be ignored in research is an ideological issue and all ontological research is more inclusive than the main stream research approaches. Every approach to research is ideological.

There are some philosophers who suggest an ontological approach in academic research because they think that the separation of a subject from its reality requires consideration of the continuities within that reality, which might change the results of that research. However, it should also be highlighted that these philosophers are not against making separations, as using the process of separation is how the human mind works. Lukacs (1975) wrote a little-known book on the need for ontological approaches in academic research. He suggested making separations but also considering continuities for ethical purposes. The contemporary philosopher Slavoj Zizek (2011) also criticized contemporary academic research because of the reductions made due to ignorance. According to Zizek, the analytic power of understanding has to be supported by the continuity between the separated parts through reason. There are also criticisms directed at ontological research. For example, Nalbantoğlu and Mücen (2010) wrote that they support ontological approaches to research, but this type of research might be too slow in comparison to positivistic or post-positivistic research approaches. This is true for ontological research, which require big data, however not all ontological research requires a longer time than other types of research.

On the other hand, the character of knowledge within the discipline of architecture is radically different from that of other disciplines. The knowledge of architecture is based on and dependent on the knowledge of many other disciplines such as structural engineering, mechanical engineering, electrical engineering, acoustic engineering, sociology, psychology, philosophy, etc., because architectural design is holistic in nature. The European Association for Architectural Education (EAAE) Charter on Architectural Research (2012) says that architecture involves, namely, art, science, design, conservation, planning, management, construction and representation, addressing issues of ethics, aesthetics, culture and society. The discipline of architecture brings these knowledge bases together in a rather practical way (Al Hürol, 1997). The presence of these different types of knowledge 
might have formed the basis of the ontological character of the discipline of architecture. However, not all of these knowledge types are seen as equally important by architects. Some architects give priority to one type of knowledge while others give priority to other types of knowledge. A great deal of academic research in architecture may also have strict limitations. Therefore, reductionism might be studied in a different way in the architectural discipline. The ontological character in architectural research is limited to research conducted on tectonics, typology studies, restoration and use of the design research method (DRM).

Is the amount of ontological academic research in architecture satisfying? Would not it be better to have more ontological research in architecture and the main stream research approaches? The author of this article thinks that ontological research has not been used sufficiently and effectively in architectural research. For example, it is believed by many architects that technical/technological thinking might be harmful to the artistic quality of architecture. This belief originates from the criticisms directed towards modern technology and the reduction of architecture through modern technology (Heidegger, 1977; Feenberg, 1999; Latour, 1992; Ellul, 1964). Architectural theory reduces technology, which reduces architecture. Therefore, most technical research in architecture does not consider the values of architecture and simply imitate research carried out in engineering disciplines. This polarization between the technical/technological dimension in architecture and the theory of architecture might be seen as one of the sources of reductionism in architecture and architectural research. However, it is possible for the technology and technical research within the field of architecture not to ignore the values of architecture. Similarly, it is better for the theory of architecture to include technology without reducing it. Reductionism can be seen in many types of research in architecture. However, academic research in architecture should be open to all types of research including ontological approaches to research. It is also necessary to question if there are any obstacles present in respect of the application of ontological research in architecture.

Ashraf Salama (2019) wrote that:

[. . . ] except for a few undertakings (Franz, 1994; Groat and Wang, 2002; Preiser et al., 2014; Lucas, 2016), there has been a glaring dearth of cognisance of the key characteristics, philosophical positions and frames of reference that pertain to methodological research in architecture and associated disciplines together with a scarcity of the scholastic endeavours involved in remedying this.

One of the claims of this article is to show that there is a future for ontological approaches to academic research including architectural research, by demonstrating that the need for ontological research has a strong basis. However, there is a research gap in respect of the: ontological approaches to academic research within all disciplines, including the field of architecture.

The main objective of this research is to describe the main characteristics and the possibilities of ontological approaches to academic research in architecture. There are various possibilities for achieving ontological academic research within the field of architecture and most of these might also apply to academic research in other disciplines. The second claim of this article is to show that there are some ideological obstacles to the application of ontological research in architecture. The characteristics and possibilities of an ontological approach to academic research in architecture are examined in this article under the following headings:

- Achieving ontological content in research.

- Achieving ontological characteristics through research methods. 
- Effect of subject position on ontological research.

\section{Methodology}

This research, is primarily based on the ethos of the author of this article, who has taught research methods courses for the post-graduate programmes of two different universities for more than 15 years. The author has, therefore, had the opportunity to practice and think about the appropriateness of various research methods in architectural academic research. The data collection process was also supported through the participatory observation of a $\mathrm{PhD}$ course (ARCH632), which is called the ontology of construction. The course was delivered by the author of this article in the Autumn term of 2016-2017 at the Eastern Mediterranean University (EMU), Department of Architecture in Famagusta, Cyprus. The aims of this course were to discuss the role of the concept of ontology in architecture and to apply ontological approaches to academic research. Hartoonian's (1994) book the "ontology of construction" was used as a source-book. This book contains an ontological analysis of the works of successful architects such as Adolf Loos, Frank Lloyd Wright, Mies van der Rohe and Louis Kahn and shows how the technical/ technological issues are integrated with artistic desire in their architecture.

The three $\mathrm{PhD}$ students, who took this course, were asked to write an article in their own field and to achieve ontological results by giving special attention to the methodologies and approaches they used. The subjects of these three articles were: other modernisms, which implies integration of local architecture with modernism, use of quantitative and qualitative research methods to examine the effect of EMU dormitories on the identity of the students and configuration of socio-cultural and architectonic dimensions in the vernacular houses of the Walled City of Nicosia.

The important sessions of this course were recorded and analysed qualitatively by using the technique of sorting. The course and these research results led the author to recall her previous experiences of research, helped her to reorganize them for the purposes of this article and enabled the posing of some critical questions about the use of ontological approaches to research in architecture.

\section{On the content of ontological approaches to academic research in architecture}

Content is the main key to understanding the ethos of ontological approaches to academic research. This type of research should cover all dimensions, which help in the understanding of the research object(s) and which are capable of changing the research results. Therefore, avoiding reductionism, which eliminates the possibility of achieving realistic results and providing rigorous research is the main aim. However, as aforementioned, deciding what dimensions are considerable is an ideological action.

Technically, there are two main types of possibilities for achieving ontological content within academic research.

(1) Quantitative + Qualitative - or - Analytical + Artistic - or - Objective + Subjective; and

(2) Being more inclusive.

\subsection{Quantitative + qualitative, analytical + artistic, objective + subjective}

Integrating quantitative content (including analytical) with qualitative content in respect of values is preferred in order not to ignore the qualitative dimension in quantitative research. 
The opposite of this situation (integrating qualitative content to quantitative research) is also suggested. These two types of content can support each other in terms of moving towards achieving ontological results. A researcher who applies an ontological approach to research is open to quantitative and qualitative types of research and does not reject any of them.

The distance between quantitative (and analytical) and qualitative has been seen as unbridgeable by many academics. First, the quantitative approaches within the natural and engineering sciences have rejected the scientific character of the quantitative research in social sciences, which were based on probability. Afterwards, both natural, engineering and social sciences (which are based on Karl Pooper's (1972) null-hypothesis development and falsification and Lakatos's (1978) research programmes) rejected the scientific character of qualitative research in arts and humanities. Finally, mixed approaches to research appeared. However, they were also rejected by many researchers within the analytical and quantitative research worlds. Immanuel Wallerstein's (1994) book: Open Social Sciences, invited academics in the social sciences to be more open-minded so as to include qualitative and mixed research approaches in the social sciences. Delanda (2013) explains this unbridgeable distance by using the concepts of analytical and artistic. According to him, it is problematic to bring these two different worlds together; the analytical is based on right and wrong, while the artistic is based on subjective values. The founder of the Critical Theory, Adorno's (1979) article: Functionalism Today, asks architects to combine the analytical and artistic in architecture. Hartoonian's (1994) book: the "ontology of construction" is one of the successful examples of the tectonics theory in which the analytical and the artistic are deeply integrated with each other.

Parallel to the attempts to bridge the gap between quantitative and qualitative research, the approaches of interdisciplinary (combining different areas within the same discipline), multidisciplinary (combining two or more closely related disciplines) and transdisciplinary research (combining two unrelated disciplines) can also be helpful in achieving ontological research by questioning the "distances" between the research areas of academics and their disciplines. The combined areas or disciplines might bring the analytical and artistic together as well as different value systems.

The unbridgeable distance between the analytical and the artistic can also be touched by using the concepts of objective and subjective or tangible and intangible. This article suggests that it is possible to analyse objective and subjective facts simultaneously in using an ontological approach to academic research. In the near-past the concept of objectivity was defined as having no feelings towards the research object, or, as maintaining an emotional distance towards the research object. Descartes (2010), cogito ergo sum presents an extreme version of this approach while stating: "I think therefore I am". Descartes is so much in doubt about his subjectivity towards the many indicators about his existence (such as his body and feelings) that he sees his thoughts as the only objective evidence for his existence. Objectivity has also been seen as a way of achieving justice through the equity provided by it. However, Adorno (1985) believes that there is barbarism in both objectivity and subjectivity. He thinks there are real and illusory dimensions of objectivity. According to him, the separation of objects from their context, other objects and researcher, is illusory. Adorno also said that our subjects have objects. According to him it is also illusory to believe that it is possible to have no feelings. Therefore, it is better to accept that being objective can only be an intention to avoid conscious subjectivity. This research also collects and analyses objective (facts which can easily be accepted by everybody) and subjective (facts which cannot be accepted by everybody-feelings and beliefs of people) data, collected during the course ARCH632. 
Some academics think that there are different paradigms - world views - (Kuhn, 1970) in academic research, which determine how one can use objective and subjective content in research. According to Grant and Giddings (2002), these paradigms are positivist (and postpositivist), interpretive, radical and poststructuralist. Positivism is based on objectivity and interpretive paradigms prefer a subjective approach. Radical and poststructuralist paradigms combine objective and subjective approaches, while radical paradigms deal with macro-political issues and poststructuralist paradigms concentrate on micro-political issues. Therefore, radical and poststructuralist approaches, which are new, are more appropriate in respect of ontological approaches to academic research. Amongst Ashraf Salama's (2019) three key philosophical positions of architectural research-positivism, anti-positivism and emancipationist - anti-positivism and emancipationist approaches to research are parallel to ontological approaches to academic research.

The problem of conscious subjectivity can be better explained by using the definition of idealism by Althusser (1993). Althusser used a metaphor to define the concepts of idealism and materialism in research. He said that idealist research is like taking a train, which you know where it is going and in materialist research you take a train that you do not know where it is going. This means that, from the onset, within the materialist type of research, you cannot be sure about the results of your research. Carrying out academic research about objective and subjective issues simultaneously can be a way of achieving ontological results in research, if the researcher's intention is to be objective towards his/her data. Even postphenomenological research, which includes first person phenomenology, requires the objective analysis of subjective data (Seamon, 2000).

\subsection{Being more inclusive}

The second type of possibility of achieving ontological content in architectural academic research is to be more inclusive in various ways such as considering different periods of time, context, hapticity, body-mind togetherness and the different points of view within architectural academic research.

- Hartoonian's (1994) highlights the importance of being more inclusive by considering different periods of time in architecture and architectural research. According to him, architecture itself is ontological in respect of time, (you cannot ignore the past, present and future in architectural design). Hartoonian showed in his book: the ontology of construction, that Adolf Loos, Frank Lloyd Wright, Mies van der Rohe and Louis Kahn managed to reflect the past in their architecture although they have used new materials and technologies. Therefore, it can be suggested that an ontological approach to research can include the effects of different periods of time in academic research on architecture.

- Social and natural contexts have been seen as a matter of ethics to consider in architecture and architectural research for a long time. Philosopher Heidegger (2001) saw continuity with context as one of the basic requirements for achieving authentic architecture. However, there are also some new concepts to consider such as sustainability and adopting an ecological approach. Therefore, it can be suggested for some ontological research in architecture to question the relationship of buildings with their contexts.

- Pallasma (2007) showed how hapticity, which includes the five senses, the effects of light, errors and a death instinct, can be a part of architecture. Therefore, it can be suggested that an ontological approach to research can be applied by including the effects of hapticity. 
- Deleuze and Guattari (2004) explained how body and mind work together to form desire mechanisms, which are the main origins of love, art and science. Becoming, which is also a valid concept in respect of architecture, is also related to the desire mechanisms. Buildings also become together with people under political, social and environmental effects. Therefore, it can be suggested that an ontological approach to research can be applied by taking into consideration the body-mind relationship, desire mechanisms and the concept of becoming in architecture.

- Deleuze and Guattari (2004) suggested including (n-1) points of view to form a healthy and strong (rhizomatic) network of thought. There can only be one approach excluded from $n$, which is that of the discriminator. Thus, it can be suggested that an ontological approach to research can be applied by including many different points of view in some architectural academic research.

Rather than realizing these suggestions in a mechanical way it is better to reach a broader intellectual horizon. This represents a higher level of achievement towards a new concept of the academic scholar.

Results and the discussions, which took place in the 632 classes, lead to the following questions, which can be asked about the use of ontological content in academic architectural research:

Q1. Are there any obstacles to using quantitative and qualitative research simultaneously in architecture?

Q2. Are there any obstacles to applying multidisciplinary and transdisciplinary research in architecture?

\section{Academic research methods in architecture and the ontological approach}

The rich content of any ontological approach to academic research requires the use of different research methods simultaneously. The issue of research methods used to achieve ontological results in academic research in architecture can be related to three different characteristics:

(1) Absence of rigid research format.

(2) Research methods to achieve ontological results.

(3) Developing ontological claims.

\subsection{Absence of rigid research format}

According to Feyerabend (1993, 1982), scientific researchers do not follow rigid methodological rules and adopting a prescriptive approach to research will limit scientific activities. The author of this article also believes that having a rigid research format might cause difficulties in research. Researchers should be able to design their research freely to be able to achieve a higher quality of research. This is especially true for any ontological approach to academic research, which might be unconventional. Rigid research format can only be one of the options for research.

\subsection{Research methods used to achieve ontological results}

The ontological approach can be achieved by using three different strategies while selecting the research methodologies. These are following: 
- The original method of ontology, in which the separations and continuities between at least two different research objects are clarified (Noy and McGuinness, 2000), can be used. In this method, the separations are determined first and then the continuities are questioned. This can be applied during the research design phase and at the end of the research one should check to be sure that the research results reflect the reality. This approach to ontology is the most appropriate approach for the application of main stream scientific approaches, which are based on the collection of one type of data (quantitative or qualitative). This approach is used in engineering sciences to avoid reductionism. Research on architectural typology is also based on this type of ontological research.

- The methodologies, which deal with ontological content, (by combining quantitative with qualitative, objective with subjective or analytic with artistic) such as Martin Heidegger's hermeneutic phenomenology, which combines objective and subjective content, post-phenomenology, which is open to the design of research in various combinations of content (Seamon, 2000), mixed methods, which combine quantitative and qualitative research in various ways (quantitative first, qualitative first, merged or embedded) (Creswell, 2014), ethnographic research, which has to be designed for each context (Whitehead, 2005), the case-study method, which provides a holistic approach to the selected case (Johanson, 2005), the DRM, which suggests that research can run parallel to a design project (Horvath, 2007; Zimmerman et al., 2007) can be selected.

- The selected research method can be supported by a supplementary research method or methods to achieve ontological character. By using different combinations of methods, quantitative and qualitative or objective and subjective or analytical and artistic, various types of content can be covered simultaneously. This research deals with objective and subjective content simultaneously as is suggested by hermeneutic phenomenology, but unlike phenomenological analysis this data has been analysed using the sorting technique.

\subsection{Developing ontological claims}

There can be three claim types which can exist in the arguments in research. These are as follows (Schippa and Nordin, 2013):

(1) Claims about physical facts: data consists of physical facts, which are collected to find out if the claim is true or false.

(2) Claims about values: data consists of physical facts and information about the values of people (subjective facts) simultaneously to establish whether or not the claimed value is significant. This article exemplifies arguments with value claims.

(3) Claims about policies: data consists of physical facts, information about the values of people, facts about the economy and social requirements.

The last two types of claims have an ontological character, mainly because they combine objective and subjective issues simultaneously. However, the first type of claim (about physical facts) is totally based on objectivity and it requires, at least, to be supported by values to become ontological and to be used in decision-making.

Similarly, combining different types of reasoning might lead to achieving an ontological character. The most common types of reasoning in academic research are induction and deduction (Schippa and Nordin, 2013). Most quantitative research studies including 
engineering experiments and statistical approaches are based on inductive reasoning. Induction is also used in qualitative research. Deduction is required in both qualitative and quantitative research. However, it is the main type of reasoning in qualitative research. Therefore, it can be suggested that some research in architecture might combine different types of reasoning and achieve ontological characteristics.

It is also necessary to think about the character of research data in ontological research. The three ways of achieving ontological results in academic research through designing research data are as follows: collecting mixed data as aforementioned, Recording and Conceptual approach to data. Different types of recording (voice recording, photographing, video filming) form the second category of data, which can lead to an ontological approach in academic research. As records reflect pieces from real life, many different types of information can be extracted from them. Recording might also enable the relating of these different types of information to each other. The conceptual approaches of collecting data were especially highlighted by philosophers. Walter Benjamin named his data as a collection. He collected his own notes between 1927 and 1940 to realize his Arcades project (Buck-Morss, 1991). Collections can be seen as sources of data, which are preferable in respect of ontological research in architecture. As with records, collections also have a holistic character. Deleuze and Guattari (1994) wrote that they worked on encounters of many different types (new research in biochemistry, new artistic approaches, etc.) to form their philosophy. According to them, encounters are the new products, which support our understanding of the hidden nature of the present and the future. Lyric poet Charles Baudelaire was collecting information about the changes in society while strolling in the city (flaneur) (Benjamin, 1983). Being a flaneur can also serve as a conceptual approach to data collection in architecture. The data used for the purposes of this article also has conceptual characteristics, as a course (ARCH632) is used to recall the ethos of the author and to form a pool for the collection of all related data. The students of ARCH632 also had difficulties in developing an original conceptual approach to their data.

Results and the discussions, which took place in the 632 classes, lead to the following questions, which can be asked about the use of ontological research methods in architecture:

Q3. Are there any obstacles to avoiding only claiming about physical facts in architecture?

Q4. Are there any obstacles to avoiding rigid research format in architectural research?

Q5. Are there any obstacles to developing an original conceptual approach for data collection in architectural research?

Q6. Are there any obstacles to analysing the same data both quantitatively and qualitatively in architectural research?

\section{The subject position in ontological academic research}

The characteristics of ontological approaches to research should also be considered before conducting this type of research, as ontological research was, in this instance, preferred, so as to avoid the reduction of the reality. In other words, if the use of other research approaches causes an ideological reduction in the reality, then ontological research is preferred as an alternative ideology.

The issues, which cannot affect the research results, can be reduced. Or, research studies can reduce the subjects to which we do not attach much importance or we do not want these subjects to affect the research results. Therefore, as aforementioned, reductions and 
limitations in research also represent our world view (Kuhn, 1970 would call it paradigm) or ideology. This means that the aim of the ontological approaches to research is to reconsider the current scientific paradigm, which is a tool of certain ideologies. Today there are many doubts about the effects of scientific research on life in general. Many researchers prefer not to ignore the harm caused to nature through their research anymore.

As aforementioned, the research content can be subjective, but the attitude of the researchers (eg. analysis techniques) cannot be subjective. The objective subject position is of major importance for all types of research whatever the world view of the researcher. Nevertheless, the claim of ontological research regarding representing reality, puts the subject position into a more ambitious category. This is why the subject position in ontological research is discussed here.

The effect of the subject position on ontological research can be analysed under the following three categories:

(1) Ideology of the subject.

(2) Empathy and criticality towards others.

(3) Consideration of different applied ethics theories simultaneously.

\subsection{Ideology of the subject}

The first category of the subject position in relation to ontological research is the ideology of the subject, which covers the metaphysical dimension of the research ideology and the avoidance of both identity thinking and the spontaneous ideology of the related profession/ discipline. Researchers should try to avoid conscious subjectivity and try to minimize subconscious subjectivity. This will also help in avoiding idealist approaches, which manipulate research and its results, according to the subjective demands of the researcher (Althusser, 1993).

- Following a secular ontology (Hartoonian, 1994) by accepting being as the base of metaphysics (Heidegger, 2005) without neglecting objective and subjective facts about it, might help the researcher to minimize her/his metaphysical subjectivity. Concentrating on being supports ontological approaches and helps in developing care towards considerations in relation to time, context and hapticity, etc.

- Avoiding identity thinking also protects the researcher from adopting a conscious or subconscious subjectivity in the research. Adorno (1994) defines identity thinking as a characteristic of the barter society, which corresponds to a group of people whose value system is based on mechanistic materialism, which is rather selfish and calculative. Therefore, ontological approaches to academic research requires a careful approach to society and the issues of identity, to avoid being subjective towards others.

- The spontaneous ideology of professions/disciplines might also lead to subjectivity in academic research. According to Althusser (2011), the spontaneous ideology of a profession concerns the differences between the professional activities of members within that profession and their self-conceptions about their profession. If a young architect works as a draftsman in an architectural office, but still thinks that she/he is an artist, this situation can be related to the spontaneous ideology of architecture. Architects usually think that they are artists even if they do not work and think as artists (Nalbantoğlu, 2000). All professions have spontaneous ideologies. The spontaneous ideology of architecture is transferred to young architects during 
architectural education (Stevens, 2002). If a researcher believes that all architects are artists (Nalbantoğlu, 2000) and imposes this belief intentionally or unintentionally in his/her research, then his/her research might not reflect reality. Thus, researchers should be aware of the spontaneous ideology of their profession/discipline so as to be able to minimize the effects of this on their research.

Ontological approaches to academic research

However, it is not easy for researchers to be aware of the effects of their idealist tendencies, identity and spontaneous ideology on their research because ideologies are usually subconsciously followed and are illusory (Eagleton, 1991).

\subsection{Empathy and criticality towards others}

The second category of the subject position, which affects ontology in research, is a combination of empathy and criticality towards others. This category covers being critical towards others, being respectful and inclusive towards others and being self-critical.

- People usually believe that a critical approach is against the world view of the others that they criticize. However, according to Adorno (1994), who is the founder of Critical Theory, it is possible to criticize others only from their perspective. The world view of others should be well-understood and it requires comparison with their actual practice to demonstrate their inner contradictions. It is important for a critical approach to help the others to recognize and accept their contradictions. Therefore, it is not acceptable to write anything rude about other peoplès academic work or research.

- Deleuze and Guattari's (2004) definition of inclusiveness as $(n-1)$ helps in clarifying the issue of being empathetic towards others. They suggest acting together with all others with the exception of the discriminator. Therefore, it is possible to criticize everybody (including oneself) in the same way, whether or not the researcher has a sincere sympathy towards them or not.

- Self-criticality is a further requirement of academic research in all disciplines including architecture. The need for self-criticality in research can be explained by the need for argument to make all types of research persuasive. A healthy argument is composed by a claim (researcher's thesis), ground (facts) supporting the claim, warrants, which demonstrate the legitimacy of these grounds, qualifiers, which demonstrate the strength of the warrants, backings for additional support for the claim and a rebuttal part, which compares the counter-arguments with the researcher`s argument (Schippa and Nordin, 2013). All of these steps are needed in a healthy argument to achieve self-criticism. A successful researcher is harsh against his/her own claim to be able to persuade others to her/his way of thinking. Heidegger (2005) relates self-criticality to daily life and the character of the person. According to him, an ontological existence can be achieved by a person through self-criticism and continuous small improvements in his/her work (he means crafts) over a long period of time. This achievement requires an intense presence within the work - being there (Dasein).

\subsection{Consideration of different applied ethics theories simultaneously}

The third category of the subject position is based on questioning the research against the requirements of different applied ethics theories, simultaneously. The most commonly used contemporary theories of applied ethics are Utilitarianism (Mill, 2001) and Deontological 
Ethics (Kant, 2002). Mill's (2001) Utilitarianism expects the greatest pleasure for the largest group of people. If you protect the majority while simultaneously also harming the minority, Utilitarian Ethics will recognize your attempt as ethical. The Deontological Ethics of Immanuel Kant (2002) is based on human will with the character given second place. If you have a strong will to follow your duty or ethical rules, you hold the highest ethical position even if you do not particularly like behaving like this. Unlike David Hume's ethics, which is based on character [1740], Kant believed that we cannot totally rely on character because the development of an ethical character requires healthy families and healthy social conditions.

These two theories usually contradict each other because Utilitarianism protects society from individuals and Deontological Ethics protects individuals from society. Thus, they can easily be used to manipulate people. For example, city-centre gentrification projects are presented as useful for the whole society, while the violation of the individual rights of the unfortunate residents by resettling them at some distance from the city etc. is almost always ignored. Therefore, it is better to apply both theories simultaneously, so as to understand the problem from the points of view of society and of the individuals, to make healthy decisions. Similarly Rawls (1999) suggests forgetting about your identity and imagining yourself in all possible identities to make objective decisions. Either this attitude should be used in academic arguments or Utilitarianism and Deontological Ethics should be considered simultaneously to make healthy argumentations.

Results and the discussions, which took place in the 632 classes, lead to the following questions, which can be asked about the subject position in ontological research in architecture:

Q7. Is spontaneous ideology of architecture an obstacle to ontological research in architecture?

Q8. Are there any obstacles to developing self-criticality within arguments in architectural research?

Q9. Are there any obstacles to using different ethical approaches simultaneously in architectural research?

\section{Conclusion}

There is a gradual and slow shift towards ontological approaches to academic research and this is also reflected in academic research in architecture. The indications for this is as follows:

- Sciences appeared in time as natural sciences, engineering sciences, social sciences and arts and humanities.

- Use of mixed research methods followed the appearance of qualitative research of arts and humanities.

- The recent research paradigms (radical and post-structural research) are based on use of mixed methods.

- The recent research on climate change, sustainability and ecology requires more inclusivity.

- Value and policy types of arguments require an ontological approach to research.

The ontological approaches to academic research is based on questioning what we include in research, what do we ignore and how does this ignorance affect the life of the world. The 
appearance of natural sciences, engineering sciences, social sciences and the arts and humanities, one by one and over a long time period has come about as a result of the needs of the market and society. The appearance of engineering sciences was due to the change in the character of production, which became faster and standardized, the character of education, which became mass education, based on standardized knowledge and the need for change towards an improved quality in production. This is reflected in architecture and civil engineering with the use of processed materials (such as reinforced concrete and steel) instead of the natural materials (stone, adobe and timber), faster production, use of standards, safer buildings against disasters etc. The appearance of social sciences was a result of the migration of villagers to the cities and the development of cities. It became necessary to gain knowledge and information about the populations in the cities. This was reflected in the architecture as the use of statistics in research about cities and urban environment. People became important. The appearance of the arts and humanities type of research was also required to discover what these new populations felt, what they preferred and what they would like to think, vote and buy. The values and feelings of people became important. These changes followed the changes in the political-economy towards neoliberalism. Therefore, the appearance of these research areas were a result of the needs of political-economy and these were directly reflected in the academic research, including the architectural research.

However, the appearance of new research paradigms, research about climate change etc. In addition, policy arguments are rather more recent and they seem to be controversial to the present political-economy. The use of mixed methods, which is the main step towards an ontological approach to research (not the method of ontology, which appeared earlier) is parallel to these controversial approaches and philosophies such as those of Zizek (2011). Similarly, interdisciplinary, multidisciplinary and transdisciplinary research opens new areas such as bio-chemistry and cultural psychology, to investigate and the knowledge produced by this research is used in many sectors of the economy. The new research paradigms and new collaborative research types are based on the production of the capitalistic need for new. They both require ontological approaches to research.

Therefore, the need for ontological approaches to academic research might or might not be due to the needs of current economy-politics. It might be due to the needs of controversial ideologies, which does not offer a safe place to the ontological approach to research within the research world. Or, it might also be due to the need for production of the new to investigate new horizons and determine the recent changes in political-economy. The presence of political-economic roots for ontological approaches to research shows that there is future for these approaches. Therefore, an increase in the number of ontological approaches to research is expected in the future. These considerations and collaborations support creativity and innovation in all disciplines including architecture.

However, being inclusive does not mean conducting research on a very broad subject and ending up with a superficial piece of research. It is worth being careful about limiting the research focus in ontological academic research in architecture too. It is possible to be inclusive in research without being superficial, with the help of a good research design, which defines the problem, the research problem, the research objective and methodology.

The analysis of this article might lead to the erroneous deduction of there being many possibilities for achieving ontological academic research in architecture. This is not true because most of the characteristics of ontological academic research are interrelated. If a researcher chooses one characteristic, many of the other characteristics might automatically follow it. These interrelated characteristics are as follows: 
- Having quantitative/qualitative, objective/subjective, analytical/artistic or tangible/ intangible content.

- Conducting interdisciplinary, multidisciplinary or transdisciplinary research.

- Having an ontological claim (value claim or policy type of claim).

- Combining different types of reasoning.

- Having mixed data.

- Being critical, using a strong argument, which compares different approaches.

- Including different time periods, context, hapticity, body-mind relationship, different points of view etc. to the content of research.

It can be stated that the possibilities of ontological academic research in architecture can be based on research methodology. These possibilities are as follows:

- Using the original method of ontology.

- Using ontological research methods.

- Using supplementary methods to achieve an ontological character.

It should be added that ontological approaches to academic research in architecture should not be seen as another prescriptive research schema. These are research approaches and their methodologies have to be designed just like the other research methods. However, ontological approaches should be the preferred approach if there are ideological doubts about the main stream research approaches in representing reality.

The critical questions, which originated from the course ARCH632 - ontology of construction - to discover the challenges of using ontological research methods in architecture can be seen below together:

Q10. Are there any obstacles to using quantitative and qualitative research simultaneously in architecture?

Q11. Are there any obstacles to applying multidisciplinary and transdisciplinary research in architecture?

Q12. Are there any obstacles to avoiding claiming only about physical facts in architecture?

Q13. Are there any obstacles to avoiding rigid research format in architectural research?

Q14. Are there any obstacles to developing an original conceptual approach for data collection in architectural research?

Q15. Are there any obstacles to analysing the same data both quantitatively and qualitatively in architectural research?

Q16. Is the spontaneous ideology of architecture an obstacle to ontological research in architecture?

Q17. Are there any obstacles to developing self-criticality within arguments in architectural research?

Q18. Are there any obstacles to using different applied ethics approaches simultaneously in architectural research? 
The author of this article would like to ask two conclusive questions, which might provoke some thinking around future research in the direction of answering the above questions. These questions are as follows:

Can the above questions, which highlight some problems in respect of using an ontological research approach in architecture, originate from the spontaneous ideology of architecture?

If so;

Is there a contradiction between the spontaneous ideology of architecture and the ideologies behind contemporary ontological research?

\section{References}

Adorno, T.W. (1979), "Functionalism today”, Oppositions, Vol. 17, pp. 31-41.

Adorno, T.W. (1985), "Subject and object", in Arato A. and Gebhardt E. (Eds), The Essential Frankfurt School Reader, New York, NY: Continuum. pp. 497-511.

Adorno, T.W. (1994), Negative Dialectics, Ashton E.B. 2nd Print. The Continuum. New York, NY.

Al Hürol, Y. (1997), "Farklı disiplinlerden alınan bilgilerin mimarlı̆ga uygunluğu (the appropriateness of the knowledge taken from other disciplines to architecture)" mimarlık eğitimi ve. . . kongresi (the congress of architectural education and ...)", TMMOB Mimarlar Odası Ankara Şubesi Yayınları, Ankara, pp. 273-281.

Althusser, L. (1993), The Future Lasts Forever: A Memoir, in Corpet O. and Boutang Y.M. , (Eds), New Press.

Althusser, L. (2011), Philosophy and the Spontaneous Philosophy of Scientists, 2nd, edition, Verso. New York, NY.

Benjamin, W. (1983), Charles Baudelaire: A Lyric Poet in the Era of High Capitalism, Zohn H. (Ed), Verso, London.

Buck-Morss, S. (1991), The Dialectics of Seeing, The MIT Press.

Creswell, J.W. (2014), Research Design: Qualitative, Quantitative and Mixed Methods Approaches, 4th ed., Sage, London.

Delanda, M. (2013), Intensive Science and Virtual Philosophy, 9th ed., Bloomsbury Academic, New York, NY.

Deleuze, G. and Guattari, F. (1994), What is Philosophy?, Tomlinson H. and Burchell G. (Eds), Columbia University Press, New York, NY.

Deleuze, G. and Guattari, F. (2004), A Thousand Plateaus: Capitalism and Schizophrenia. (Trans: Brian Massumi), 5th ed., Continuum. New York, NY.

Descartes, R. (2010), The Principles of Philosophy, Veitch John (Trans) Kessinger Legacy Reprints.

(EAAE) Charter on Architectural Research (2012), available at: www.eaae.be/wp-content/uploads/2014/ 05/2012-09-03_EAAE-Charter-on-Architectural-Research.pdf (accessed 6 February 2017).

Eagleton, T. (1991), Ideology: An Introduction, Verso. London, pp. 1-2.

Ellul, J. (1964), The Technological Society, Wilkinson J. (Trans) Alfred A. Knopf, Inc. and Random House, Inc. New York, NY.

Feenberg, A. (1999), Questioning Technology, Routledge, London.

Feyerabend, P. (1982), Science in a Free Society, Verso, London.

Feyerabend, P. (1993), Against Method - Outline of an Anarchistic Theory of Knowledge, 3rd ed., Verso, London.

Franz, J.M. (1994), “A critical framework for methodological research in architecture”, Design Studies, Vol. 15 No. 4, pp. 433-447. 
Grant, B. and Giddings, L. (2002), "Making sense of methodologies: a paradigm framework for the novice researcher", Contemporary Nurse, Vol. 13 No. 1, pp. 10-28.

Groat, L. and Wang, D. (2002), Architectural Research Methods, John Wiley. New York, NY.

Hartoonian, G. (1994), Ontology of Construction, Cambridge University Press.

Heidegger, M. (1977), Question concerning Technology, and Other Essays, (Trans) Lovitt W. Harper and Row, Publishers, Inc. New York, NY.

Heidegger, M. (2001), Poetry, Language, Thought, (Trans) Hofstadter A. Harper and Row, Publishers. New York, NY.

Heidegger, M. (2005), Being and Time, 25th ed., Macquarrie John, Edward Robinson (Trans) Blackwell Publishing. Oxford.

Horvath, I. (2007), “Comparison of three methodological approaches of design research", International Conference on Engineering Design ICED.07. 28-31 August 2007. Cite des Scientes et de L'industrie. Paris, p. 341.

Hume, D. (1740), "Treatise of human nature. Book III: morals", available at: www.earlymoderntexts. com/assets/pdfs/hume1740book3.pdf (accessed 29 January 2017).

Johanson, R. (2005), "On case study methodology", Vestbro D.U., Hurol Y. and Wilkinson N. (Eds), Methodologies in Housing Research, Urban International Press, GB, pp. 30-40.

Kant, I. (2002), Groundwork for the Metaphysics of Morals, (ed: Allen Wood Yale University Press. London.

Kuhn, T. (1970), The Structure of Scientific Revolutions, The University of Chicago Press, Chicago.

Lakatos, I. (1978), The Methodology of Scientific Research Programmes: Philosophical Papers Volume 1, Cambridge University Press, Cambridge.

Latour, B. (1992), "Where are the missing masses? The sociology of a few mundane artifacts", In W. Bijker and J. Law, (Eds) Shaping Technology/Building Society: Studies in Sociotechnical Change, MIT Press. Cambridge. pp. 225-258.

Lucas, R. (2016), Research Methods for Architecture, Laurence King Publishing. London.

Lukacs, G. (1975), “The ontological basis of human thought and action”, The Philosophical Forum. VII/ 1. Fall, pp. 22-37.

Mill, J.S. (2001), Utilitarianism, in George Sher (Ed) 2nd ed., Hackett Publishing Company, Indianapolis.

Nalbantoğlu, H.Ü. (2000), "Yaratıcı deha: Bir modern sanat tabusunun anatomisi" (creative genius: the anatomy of a modern art taboo)”, Çizgi Ötesinden: Üniversite: Sanat: Mimarhk, ODTÜ Mimarlık Fakültesi Yayınları, Ankara, pp. 85-104.

Nalbantoğlu, H.Ü. and Mücen, B. (2010), "György lukacs'nn ontolojik arayışı” (ontological search of györgy lukacs)”, Toplum ve Bilim, No. 119, pp. 57-83.

Noy, N. and McGuinness, D. (2000), "Ontology development 101: a guide to create your first ontology", available at: https://protege.stanford.edu/publications/ontology_development/ontology101.pdf (accessed 24 September 2017).

Pallasma, J. (2007), The Eye of the Skin - Architecture and the Senses, 2nd ed., John Wiley and Sons, Sussex.

Peirce, C.S. (1955), "The principles of phenomenology”, in Buchler J. (Ed), Philosophical Writings of Peirce, Dower Publications, New York, NY. pp. 74-97.

Popper, K.R. (1972), Objective Knowledge: An Evolutionary Approach, Clarendon Press, Oxford.

Preiser, Wolfgang F.E., Davis, Aaron T., Salama, Ashraf M. and Hardy, A. (Eds) (2014), Architecture beyond Criticism: Expert Judgment and Performance Evaluation, Routledge, London.

Rawls, J. (1999), A Theory of Justice, 2nd ed., Harvard University Press.

Salama, A.M. (2019), "Methodological research in architecture and allied disciplines: philosophical positions, frames of reference, and spheres of inquiry", Archnet-IJAR: International Journal of Architectural Research, Vol. 13 No. 1, pp. 8-24. 
Schippa, E. and Nordin, J. (2013), Keeping Faith with Reason - A Theory of Practical Argumentation, Pearson. Boston.

Seamon, D. (2000), "A way of seeing people and place: phenomenology in environment-behavior research”, in Wapner, S., Demick, J., T. Yamamoto and Minami H., (Eds) Theoretical Perspectives in Environment-Behavior Research, Plenum. New York, NY, pp. 157-178.

Ontological approaches to academic research

Stevens, G. (2002), The Fovoured Circle - The Social Foundations of Architectural Distinction, The MIT Press.

Wallerstein, I. (1994), Open Social Sciences, Stanford University Press, CA.

Whitehead, T.L. (2005), "Basic classical ethnographic research methods", available at: www.cusag. umd.edu/documents/workingpapers/classicalethnomethods.pdf (accessed 5 February 2017).

Zimmerman, J. Forlizzi, J. and Evenson, S. (2007), "Research through design as a method for interaction design research in HCl", http://repository.cmu.edu/cgi/viewcontent.cgi?article=1041\&context= hcii (accessed 7 February 2017).

Zizek, S. (2011), "With Hegel beyond Hegel”, Criticism, Vol. 53 No. 2, p. 6.

\section{About the author}

Yonca Hurol has worked in the Department of Architecture at the EMU since 1998. Her fields of research include the tectonics of structural systems, architectural design of structural systems, tectonics, ethics in architecture and architectural research. She has written a book entitled: "The Tectonics of Structural Systems - An Architectural Approach", which was published by Routledge of Taylor and Francis in 2016. Yonca Hurol can be contacted at: yoncahurol55@gmail.com

For instructions on how to order reprints of this article, please visit our website: www.emeraldgrouppublishing.com/licensing/reprints.htm Or contact us for further details: permissions@emeraldinsight.com 